\title{
GENETIC TREND AND RELATIONSHIP OF MEATINESS TRAITS OF DIFFERENT BREED PIGS RAISED IN LITHUANIA
}

\author{
Ramutis Klimas and Asta Klimienè \\ Šiauliai University, P. Višinskio 19, Šiauliai, LT-77156, LITHUANIA \\ E-MAIL: BTMC@CR.SU.LT
}

Communicated by İzaks Rašals

The purpose of this study was to determine the genetic trend of leanness for purebred pigs, and to determine the relations between meatiness traits, age and live weight of animals. The estimation of meatiness traits (backfat and loin lean thickness, lean meat percentage) of purebred Lithuanian White (LW), Large White (La.W), Yorkshire (Y), Landrace (L), Duroc (D) and Pietrain $(P)$ pigs grown in breeding centres was evaluated by apparatus Piglog 105, during 2000-2006. In 2006, the average lean meat percentage of purebred pigs in the breeding centres of Lithuania ranged from $56.9 \%$ (LW) to 59.5\% (D). During the observation period (2000-2006), the genetic trend of the leanness of $L W$ was $6.9 \%(\mathrm{P}<0.001)$, La.W and L, respectively, was 2.2 and $2.5 \%$ $(\mathrm{P}<0.01), D$ was $1.6 \%(\mathrm{P}<0.05), Y$ was $0.2 \%$ and $\mathrm{P}$ was $0.6 \%$. A higher genetic trend of the leanness in the LW pig breed can be explained by import of English La.W boars. Correlation analysis showed that lean meat percentage of pigs is more related to backfat thickness ( $r=$ from -0.84 to $-0.95, \mathrm{P}<0.001$ ), than to loin lean thickness ( $r=$ from 0.11 to 0.30$)$. Live weight of pigs had more influence on mentioned meatiness traits than age.

Key words: pigs, meatiness traits, selection, correlation.

\section{INTRODUCTION}

Meatiness of pig depends on numerous factors. Breed is one of them (De Vries and Kanis, 1994; Somelar et al., 2000; Klimienè and Klimas, 2001; Michalska et al., 2007). Fat and lean tissue differ at different periods of pig weight in various pig breeds (Kolstad, 2000). However, backfat thickness is an indicator of pig leanness, because a lower backfat thickness is associated with a higher lean meat content. Also, it has been shown (Vege et al., 2000; Tänavots et al., 2002; Veide, 2002) that the correlation coefficients for these traits are highly negative $(\mathrm{r}=$ till -0.6 to -0.9$)$.

Pig breeding in Lithuania is a traditional branch of animal husbandry. Pork accounts over 50\% of the total meat production. With increasing demands for lean pork, selection of pigs in the country is developed namely by this trend. Selection of boars and sows is carried out in the breeding centres is based on half carcass length, backfat thickness, loin lean area and weight of ham of progeny fattened at a control fattening station and slaughtered at average weight $95 \mathrm{~kg}$. Since 1996 (Klimas and Klimienè, 2000), breeding progeny in the breeding centres of Lithuania have been selected for backfat thickness and lean meat percentage determined by in vivo using the ultrasonic apparatus Piglog 105 (phenotypical evaluation). By the end of 2006, at the breeding centres about $25 \%$ of all purebred pigs were Lithuanian White, 13\%-Large White, 18\%-Yorkshire, 42\%-Landrace, and
2\%-Lithuanian native pigs (gene pool), Duroc and Pietrain (Rekštys, 2006).

The purpose of this study was to determine the genetic trend of leanness for purebred pigs, and to determine the relations between meatiness traits, age and live weight of animals.

\section{MATERIALS AND METHODS}

Lean meat percentage (leanness) and other meatiness traits (backfat and loin lean thickness) of purebred Lithuanian White (LW), Large White (La. W), Yorkshire (Y), Landrace (L), Duroc (D) and Pietrain (P) pigs grown in the breeding centres were estimated using an ultrasonic apparatus Piglog 105, during 2000-2006. The number of tested purebred pigs of different breed for determination of the genetic trend of the leanness, is presented in Table 1 (total $\mathrm{n}=$ 26 953). Correlation coefficient (r) of meatiness traits with age and live weight of breeding progeny $(n=5402)$ are defined.

Phenotypic evaluation of pig meatiness traits. At breeding centres measurements were made for breeding progeny at $85-110 \mathrm{~kg}$ live weight. Lean meat percentage was determined with a Piglog 105 by measuring the backfat thickness (mm) on live pigs at two points (Anonymous, 1991):

1) between the 3rd and 4th last lumbar vertebrae and $7 \mathrm{~cm}$ sideways from the middle dorsal line (FAT-1); 
Table 1

DATA FOR LEAN MEAT CONTENT IN PIGS OF DIFFERENT BREEDS MEASURED USING A PIGLOG 105

\begin{tabular}{|c|c|c|c|c|c|}
\hline \multirow[t]{2}{*}{ Parameter } & \multicolumn{4}{|c|}{ Year } & \multirow{2}{*}{$\begin{array}{c}\text { Comparison }( \pm) \\
2006 / 2000\end{array}$} \\
\hline & 2000 & 2002 & 2004 & 2006 & \\
\hline \multicolumn{6}{|c|}{ Lithuanian White (LW) } \\
\hline No. of pigs & 1939 & 2320 & 1790 & 1846 & \\
\hline Lean meat $\%$ & 50.0 & 51.9 & 56.7 & 56.9 & $+6.9 * * *$ \\
\hline \multicolumn{6}{|c|}{ Large White (La.W) } \\
\hline No. of pigs & 416 & 335 & 550 & 1285 & \\
\hline Lean meat $\%$ & 56.3 & 58.1 & 58.4 & 58.5 & $+2.2 * *$ \\
\hline \multicolumn{6}{|c|}{ Yorkshire (Y) } \\
\hline No. of pigs & 1348 & 1371 & 1386 & 1351 & \\
\hline Lean meat $\%$ & 57.8 & 57.8 & 57.6 & 58.0 & +0.2 \\
\hline \multicolumn{6}{|c|}{ Landrace (L) } \\
\hline No. of pigs & 1479 & 1726 & 3779 & 3218 & \\
\hline Lean meat $\%$ & 56.3 & 57.6 & 58.1 & 58.8 & $+2.5 * *$ \\
\hline \multicolumn{6}{|c|}{ Duroc (D) } \\
\hline No. of pigs & 60 & 59 & 106 & 43 & \\
\hline Lean meat $\%$ & 57.9 & 59.7 & 59.1 & 59.5 & $+1.6^{*}$ \\
\hline \multicolumn{6}{|c|}{ Pietrain $(\mathrm{P})$} \\
\hline No. of pigs & 223 & 153 & 104 & 66 & \\
\hline Lean meat \% & 60.0 & 58.5 & 58.7 & 59.4 & -0.6 \\
\hline
\end{tabular}

2) $10 \mathrm{~cm}$ from the last rib towards the cranial part and $7 \mathrm{~cm}$ sideways from the middle dorsal line (FAT-2). The thickness of the loin lean (musculus longissimus dorsi) is also measured at this point.

The lean meat percentage was determined according to the in-coded Piglog 105 formula. Age (in days) and live weight of pigs were entered in the apparatus programme before backfat measurements.

Statistical analysis. Data were processed using the statistical package Statistica for Windows version 6.0 (StatSoft,
2001) following Tucker (2003). Differences were considered significant when $P<0.05$.

\section{RESULTS}

In 2006, at the breeding centres of the country the average lean meat percentage of Lithuanian White pigs was $56.9 \%$, that of Yorkshire $58.0 \%$, Large White $58.5 \%$, Landrace $58.8 \%$, Pietrain $59.4 \%$ and Duroc $59.5 \%$ (Table 1).

Compared with the data for 2000, the leanness of Lithuanian White pigs in 2006 has increased by $6.9 \%(P<0.001)$, that of Large White and Landrace, respectively, by 2.2 and $2.5 \%(P<0.01)$, Duroc by $1.6 \%(P<0.05)$, Yorkshire by $0.2 \%$; and lean tissue deposition in Pietrain pigs decreased by $0.6 \%$ (Table 1 and Fig. 1).

Relationships of meatiness traits of pigs for different breeds are shown in Table 2. The highest correlation coefficients were obtained between backfat thickness in both points and lean meat percentage ( $r=$ from -0.84 to -0.95 ), indicating that a thinner backfat is associated with higher relative muscularity of pigs $(P<0.001)$. Much smaller influence on the lean meat percentage of pigs had thickness of loin lean $(r=$ from 0.11 to 0.30 ). High positive correlation coefficients were found between backfat thickness in both points $(\mathrm{r}=$ from 0.69 to 0.84 ). Therefore, thickening of backfat is similar at both back points $(P<0.001)$. However, both in the first point (FAT-1) and in the second (FAT-2) relationships between backfat and loin lean thickness differed widely among genotypes $(r=-0.04$ to 0.51$)$.

Meatiness traits of breeding progeny were related to age and live weight (Table 2). Correlation between age of pigs and backfat thickness in both points was positive in all groups ( $r=$ from 0.01 to 0.35 ), while it was negative between age and relative muscularity in 5 groups $(\mathrm{r}=$ from -0.01 to $-0.29)$, but slightly positive $(r=0.10)$ and insignificantly for Pietrains.

Relationships between live weight and meatiness traits of pigs were close and not contradictory. With increasing mass

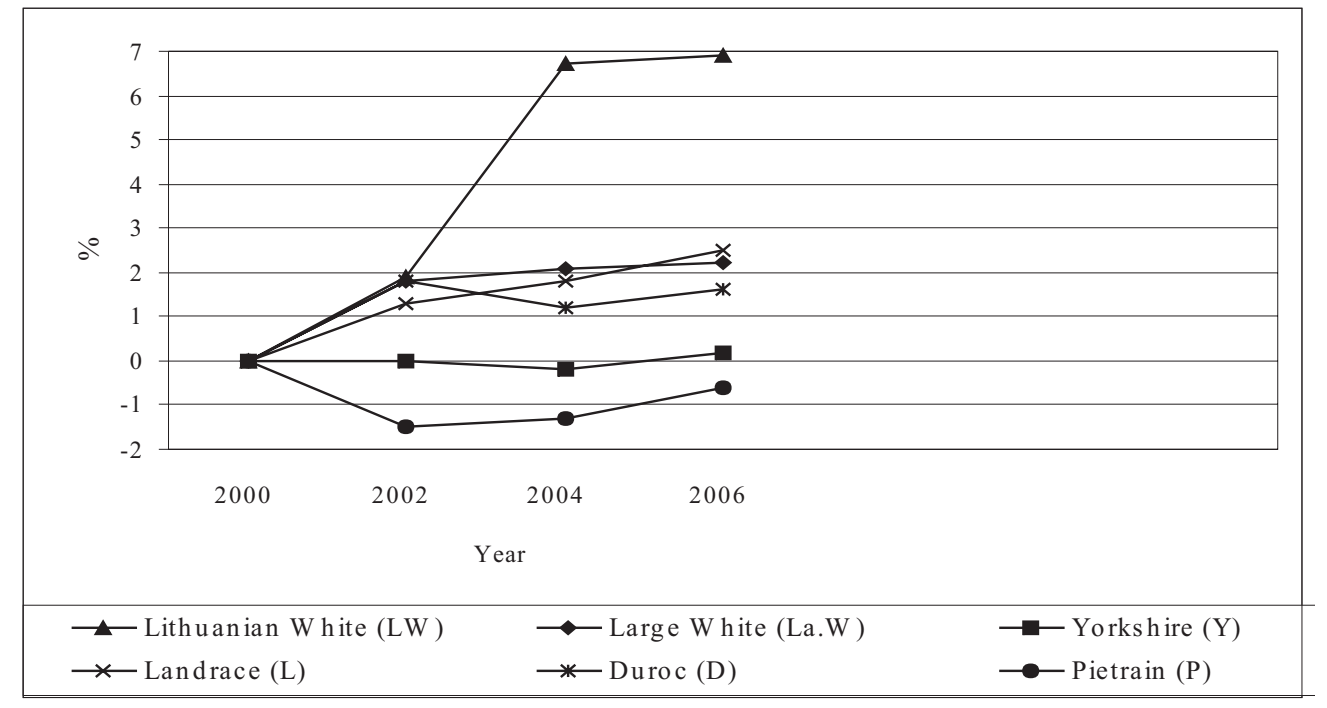

Fig. 1. Genetic trend of leanness in the pig breeding centres. 
CORRELATION COEFFICIENTS (r) OF MEATINESS TRAITS WITH AGE AND LIVE WEIGHT OF PIG DIFFERENT BREEDS

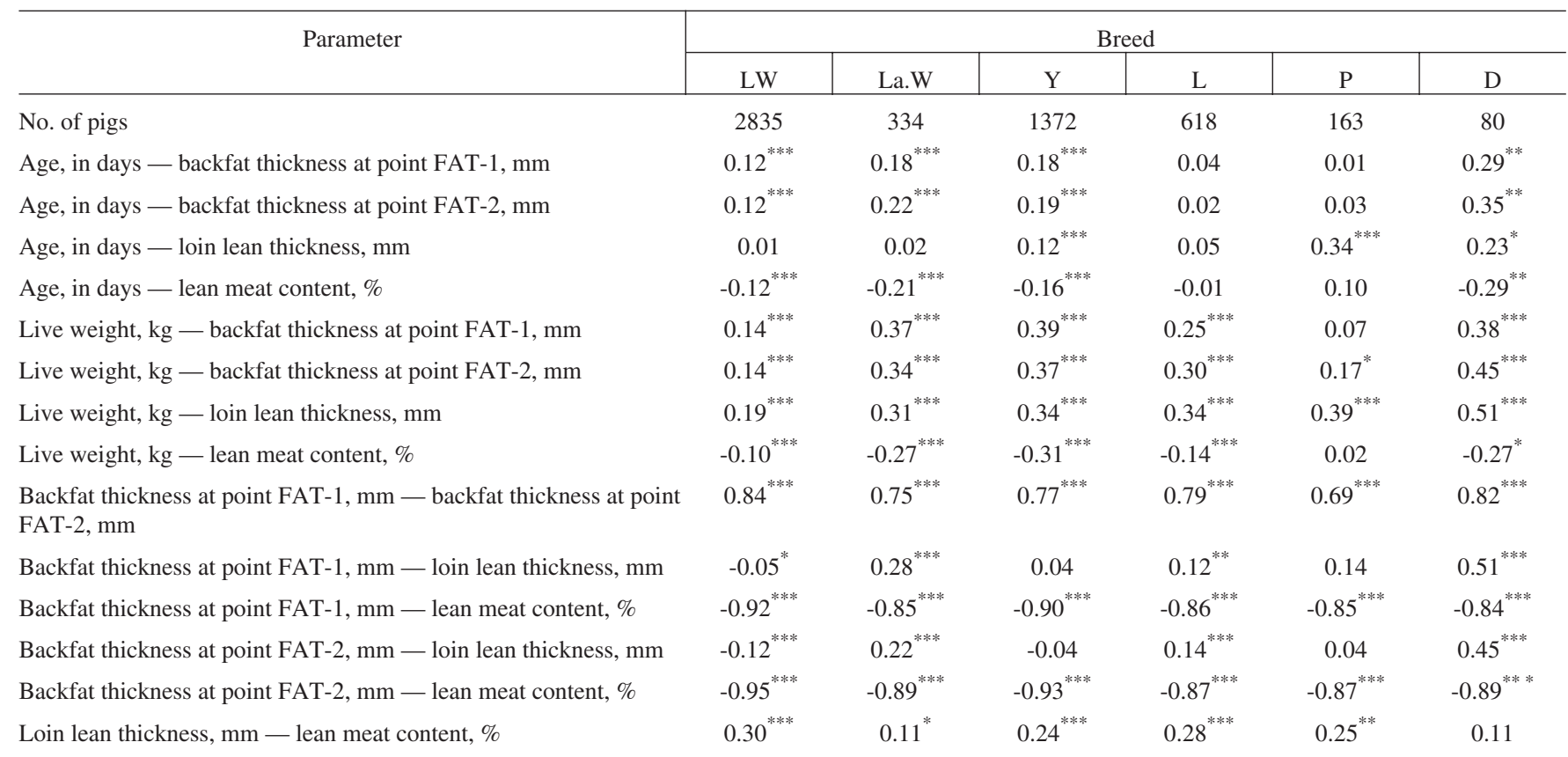

$\overline{\text { For abbreviations see Table } 1 .{ }^{*} P<0.05 ;{ }^{* *} P<0.01 ;{ }^{* * *} P<0.001}$

of the body, thickness of backfat ( $\mathrm{r}=$ from 0.07 to 0.45$)$ and thickness of loin lean ( $\mathrm{r}=$ from 0.19 to $0.51, P<0.001)$ of breeding progeny also increased, when relative muscularity in many groups (in five groups) was decreasing ( $\mathrm{r}=$ from -0.10 to -0.31$)$. There was no correlation between live weight and relative muscularity $(r=0.02)$ for the Pietrains group.

\section{DISCUSSION}

Pig breeds in Lithuania are classified into three groups:

- maternal breed - Lithuanian native, Lithuanian White, Large White/Yorkshire;

- intermediate breed - Landrace;

- paternal breed - Duroc, Pietrain and their hybrids with Landrace pigs.

The breeding progeny is raised and distributed by 43 pig breeding centres. By the end of the year 2006, about $8 \%$ of all pigs were bred in these centres (Rekštys, 2006). Pig selection carried out in breeding centres is directed towards higher litter size and milk yield and improvement of fattening and carcass traits. The main quality indicator of pig carcasses is the percentage of lean meat. Studies of genetic factors and search and introduction of more progressive selection methods become very important due to increased demand for high quality pork.

According to the Piglog 105 data obtained in 2006, the average lean meat percentage of purebred pigs in the breeding centres of Lithuania ranged from $56.9 \%$ (Lithuanian White) to $59.5 \%$ (Duroc), which indicated that the selection of breeding progeny in Lithuanian breeding centres shown by a phenotypic method of meatiness evaluation (Piglog 105), was highly effective. During the observation period (20002006), the genetic trend of the muscularity of the pigs ranged from $6.9 \%$ (Lithuanian White) to $0.6 \%$ (Pietrain). By their leanness, Lithuanian Whites are becoming comparable to Yorkshires and Large Whites bred in the country. A higher genetic trend of the leanness of the Lithuanian White pig breed is probably due to import of English Large White boars (Klimas et al., 2005). English Large Whites had the biggest influence on nurture of Lithuanian Whites (Makoveckas, 1986), and additional infusion of blood of this breed may be considered as pure breeding. According to the used schemes of breeding, improvement of genetic potential of the population of purebred Lithuanian Whites with boars of the English Large White breed started in 2002 in nine breeding centres (Klimas et al., 2004). During the study period, leanness of Yorkshires and Pietrains was not statistically significant. However, muscularity of Pietrain pigs decreased by $0.6 \%$ indicating difficultly of this breed in adapting in Lithuania.

Carrying out the selection of pigs according to several productivity traits, it is necessary to know their interrelation. The magnitude of correlation between different production traits of pigs depends on many factors, the most important being breed, genetic structure of the herd, the level of productivity and environmental conditions (Nicholas, 1996; Vege et al., 2000; Tänavots et al., 2002; Hoste, 2003). Correlations of meatiness traits of pigs bred in Lithuania in most cases have been determined by evaluating carcasses (Klimas and Klimienè, 2000; Mikelènas and Štuopytė, 
2000). Correlations between meatiness traits, evaluated in breeding centres using the apparatus Piglog 105, and age and live weight of investigated animals for most breeds were determined for the first time. Depending on breed, lean meat percentage of pigs was more related to their backfat thickness ( $\mathrm{r}=$ from -0.84 to $-0.95, P<0.001$ ), than to loin lean thickness ( $r=$ from 0.11 to 0.30 ). Increase of backfat thickness in one point of the back is similar to that in the other point of the back ( $\mathrm{r}=$ from 0.69 to $0.84, P<0.001)$. It was also found that live weight of pigs had a greater influence on meatiness traits than age.

\section{REFERENCES}

Anonymous (1991) PIGLOG 105 Users Guide. Soborg, Denmark: SFK Technology, $14 \mathrm{pp}$.

Anonymous (2001). StatSoft, Inc. Statistica for Windows version 6.0. http://www.statsoft.com

De Vries, A.G., Kanis, E. (1994). Selection for efficiency of lean tissue deposition in pigs. In: Principles of Pig Science. (pp. 23-41). Cole, D.J.A., Wiseman, J., Varley, A.A. (eds.). Nottingham Univ. Press.

Hoste, S. (2003). Genotype environment interactions. In: Perspectives in Pig Science. (pp. 25-39). Wiseman, J., Varley, M.A., Kemp, B. (eds.). Nottingham Univ. Press.

Klimas, R., Klimienè, A. (2000). Phenotypic evaluation of the leanness of breeding pigs in Lithuania. Agraarteadus, 2, 176-181.

Klimas, R., Klimienè, A. (2000). Phenotypic correlation of pig productivity traits. Biologija, 3, 46-48.

Klimas, R., Klimienè, A., Rimkevičius, S. (2004). Changes in selection of purebred Lithuanian White pigs. Animal Breeding in the Baltics. Tartu, pp. $119-122$

Klimas, R., Klimienè, A., Rimkevičius, S. (2005). Fattening and carcass traits of Lithuanian White pigs with different part of English Large White blood. Proceedings of the $11^{\text {th }}$ Baltic Animal Breeding and Genetics Conference. Palanga, pp. 93-96.
Klimienè, A., Klimas, R. (2001). The leanness of pigs raised in Lithuania. Proceedings of the $7^{\text {th }}$ Baltic Animal Breeding Conference. Tartu, pp. 109-113.

Kolstad, K. (2000). Fat deposition and distribution in three genetic lines of pigs from 10 to $105 \mathrm{~kg}$ liveweight. In: Quality of meat and fat in pigs as affected by genetics and nutrition. (pp. 199-202). Wenk, C., Fernandez, J.A., Dupuis, M. (eds.). Wageningen.

Makoveckas, R. (1986). Lietuvos baltosios kiaulès [Lithuanian White pigs]. Vilnius. 299 pp. (in Lithuanian).

Michalska, G., Nowachowicz, J., Bucek, T., Wasilewski, D. (2007). Fat and meat content of crossbred pigs came from reciprocal crossing of Polish Large White and Polish Landrace breed. Animal Science, 1, pp. 84-85.

Mikelėnas, A., Štuopyte, N. (2000). Kiaulių skerdienos kokybės ir ūkiškai naudingų požymių koreliacija [Correlation between carcass and farming quality of pigs]. Veterinarija ir Zootechnika, 11(33), 53-56. (in Lithuanian).

Nicholas, F.W. (1996). Selection within populations. In: Introduction to Veterinary Genetics. Oxford University Press, pp. 261-272.

Rekštys, V. (2006). Kiauliu veislininkystès apyskaita [Pig breeding records]. Baisogala. 58 pp. (in Lithuanian).

Somelar, E., Tänavots, A., Saveli, O., Eilart, K., Poldvere, A., Kaart, T. (2000). Prediction of meat traits of different pig breed combinations in Estonia. Proceedings of the $6^{\text {th }}$ Baltic Animal Breeding Conference. Jelgava, pp. 116-121.

Tänavots, A., Kaart, T., Saveli, O. (2002). Heritability and correlation of meat and fertility traits in pigs in Estonia. Veterinarija ir Zootechnika, 19(41), 106-108.

Tucker, L. A. (2003). Simplistic Statistics. A Basic Guide to the Statistical Analysis of Biological Data. UK, Welton Lincoln: Chalcomble Publications, $65 \mathrm{pp}$.

Vege, A., Berzina, Z., Paura, L., Jansone, M. (2000). Lean meat yield from pigs carcass measurements indices. Proceedings of the $6^{\text {th }}$ Baltic Animal Breeding Conference. Jelgava, pp.123-127.

Veide, Dz. (2002). Trait genetic trend - indicator of selection progress. Proceedings of the $8^{\text {th }}$ Baltic Animal Breeding and Genetics Conference. Kaunas, pp. 96.

Received 10 October 2007

\section{ĢENĒTISKAIS UZLABOJUMS UN GAḶAS İPAŠĪBU PAZĪMJU SAVSTARPĒJĀ SAISTĪBA DAŽĀDĀM LIETUVĀ AUDZĒTĀM CŪKU ŠK়IRNĒM}

Būtiskākais Lietuvā audzēto cūku ǵenētiskais uzlabojums saistīts ar angḷu šķirnes Large White iekrustošanu. Sniegtas korelācijas starp galvenajām gaḷas īpašības nosakošajām pazīmēm un analizēta to ietekme uz gaḷas kvalitāti. 